\title{
Cyanate attenuates insulin secretion in cultured pancreatic $\beta$ cells
}

\author{
EUNYOUNG HA \\ Department of Biochemistry, School of Medicine, Keimyung University, Daegu, Republic of Korea
}

Received December 8, 2011; Accepted March 2, 2012

DOI: $10.3892 / \mathrm{mmr} .2012 .837$

\begin{abstract}
The vast majority of long-term complications in transplanted patients are associated with cardiovascular disease. Previously, an alternative and dominant mechanism for cyanate formation in atherosclerotic lesions has been discovered. This study was designed to determine the effect of cyanate on insulin secretion in cultured pancreatic $\beta$ cells (INS-1 cells). The cytotoxicity of cyanate was determined by 3-(4,5-Desethyithiazol-2-yl)-2,5-diphenyltetrazolium bromide assay. Insulin secretion was measured by ELISA in cyanatetreated INS-1 cells. Reactive oxygen species (ROS) generation was also determined by measuring the fluorescent oxidized product of 2,7-dichlorefluorescein in cyanate-treated INS-1 cells. FACS analysis was carried out to determine the effect of cyanate on the apoptosis of INS-1 cells. Firstly, we found that cyanate, within concentration ranges in which no cytotoxic effect was observed $(0.01,0.1$ and $1.0 \mathrm{mM})$, decreased insulin secretion dose-dependently in both non-glucose-stimulated and glucose-stimulated INS-1 cells. Cyanate at a $1.0 \mathrm{mM}$ concentration inhibited insulin secretion by more than $50 \%$ in non-glucose-stimulated cells and glucose (5 and $10 \mathrm{mM}$ )-stimulated cells. Cyanate, however, did not affect ROS generation. Furthermore, no pro- or anti-apoptotic effect was observed in cyanate-treated INS-1 cells. The results in this study suggest the possible inhibitory effect of cyanate on insulin secretion in INS-1 pancreatic $\beta$ cells. The inhibitory effect was not mediated either by ROS generation or by apoptosis. Further studies to determine the underlying mechanisms will be of benefit.
\end{abstract}

\section{Introduction}

At physiological $\mathrm{pH}$ and body temperature, $0.8 \%$ of the molar concentration of urea is spontaneously converted to cyanate (1). Cyanate subsequently reacts irreversibly with the $\mathrm{N}$-terminal groups of amino acids, peptides and many proteins by a process known as carbamylation (2-4). Accordingly, the

Correspondence to: Dr Eunyoung Ha, Department of Biochemistry, Keimyung University School of Medicine, 194 Dong San Dong, Daegu 700-712, Republic of Korea

E-mail: eyha@dsmc.or.kr

Key words: cyanate, insulin, reactive oxygen species, pancreatic $\beta$ cells potential role of cyanate and carbamylation has to date been investigated only in the context of uremia $(2,5-7)$. Proteins isolated from patients with chronic renal failure and end-stage renal disease have been shown to be easily carbamylated due to the urea-derived high concentrations of cyanate.

In a previous study, the discovery of an alternative and quantitatively dominant mechanism for cyanate formation at the sites of inflammation was reported. The study clearly proves that cyanate $\left(\mathrm{OCN}^{-}\right)$is produced by myeloperoxidase (MPO), a heme protein derived from leukocytes, and that cyanatemediated protein carbamylation occurs under physiologically relevant conditions (8).

It is well known that MPO is catalytically active in chronic inflammatory diseases, such as atherosclerosis, in an $\mathrm{H}_{2} \mathrm{O}_{2}$ dependent manner $(9,10)$. Elevated levels of MPO have been observed in both type 1 and 2 diabetes mellitus (11). The role of MPO-generated cyanate, however, is largely unknown. Therefore, the present study was designed to determine the effect of cyanate on pancreatic $\beta$ cells.

\section{Materials and methods}

Cell culture. The INS-1 glucose-sensitive pancreatic cell line was maintained at $37^{\circ} \mathrm{C}$ in a humidified atmosphere of $95 \%$ air and $5 \% \mathrm{CO}_{2}$ in RPMI (WelGENE, Daegu, Korea) supplemented with $10 \%$ heat-inactivated fetal bovine serum (WelGENE), $1 \%$ sodium pyruvate and $0.35 \%$ mercaptoethanol.

Cell viability. Cell viability of INS-1 cells was determined with 3-(4,5-Desethyithiazol-2-yl)-2,5-diphenyltetrazolium bromide (MTT; Sigma-Aldrich, USA) assay to the colored formazan product by mitochondrial lactate dehydrogenase activity in viable cells. Briefly, after incubating INS-1 cells with cyanate at different concentrations, MTT solution was added to a final concentrion of $0.5 \mathrm{mg} / \mathrm{ml}$, and the cells were further incubated for $4 \mathrm{~h}$. The dark blue formazan crystals formed in intact cells were solubilized with DMSO and absorbance at $492 \mathrm{~nm}$ was measured with a microplate reader.

Flow cytometry analysis. INS-1 cells were suspended in $100 \mu 1$ of PBS, and $100 \mu \mathrm{l}$ of $95 \%$ ethanol were added while vortexing. The cells were incubated at $4^{\circ} \mathrm{C}$ for $1 \mathrm{~h}$, washed with PBS and resuspended in $250 \mathrm{ml}$ of propidium iodide (PI) solution $(0.1 \%$ NP40, 0.1\% Trisodium citrate, 50X PI) together with $50 \mu \mathrm{g} /$ $\mathrm{ml}$ of RNase. Incubation was continued at $4^{\circ} \mathrm{C}$ for $20 \mathrm{~min}$. The stained cells were analyzed by FACScan (Becton-Dickinson, Franklin Lakes, NJ, USA). 
Measurement of reactive oxygen species (ROS). INS-1 cells $(10,000$ cells/well) seeded in 96-well plates were grown overnight. The cells were loaded with $30 \mathrm{~mol} / \mathrm{l}$ 2,7-dichlorefluorescein diacetate (Sigma; St. Louis, MO, USA) for $45 \mathrm{~min}$ at $37^{\circ} \mathrm{C}$ in culture medium. The cells were washed with phosphate-buffered saline solution containing $1 \%$ fetal bovine serum. Fluorescence was measured at $485-\mathrm{nm}$ excitation and $535-\mathrm{nm}$ emission every $5 \mathrm{~min}$ for $60 \mathrm{~min}$ at $37^{\circ} \mathrm{C}$ using a VICTOR3 multilabel counter (PerkinElmer, Boston, MA, USA). The changes in relative fluorescence unit (RFU) from zero time were expressed as $\delta$ RFU.

Enzyme-linked immunosorbent assay. Secreted insulin was measured using $25 \mu \mathrm{l}$ of diluted (x10) supernatant from each well $(100,000 \mathrm{cells} / \mathrm{ml} ; 200 \mu \mathrm{l})$ of 96 -well plates using the Insulin (Rat) Ultra Sensitive ELISA kit from ALPCO Diagnostics (Windham, NM, USA). In brief, $25 \mu 1$ standard, control and unknown were incubated separately with $75 \mu 1$ conjugate solution, containing insulin antibody, for $120 \mathrm{~min}$ at room temperature. Plates were washed 6 times manually and allowed to react with 3,3',5,5'-tetramethylbenzidine peroxidase substrate for at least $15 \mathrm{~min}$ at room temperature. Reactions were stopped by the addition of $50 \mu \mathrm{l}$ stop solution. Finally, bi-chromatic absorbance measurement with reference at 650 and $450 \mathrm{~nm}$ was performed using a Benchmark Biorad Microplate spectrophotometric reader (BioRad, Sunnyville, CA, USA).

Statistical analysis. The results were expressed as the means \pm SD. Statistical evaluation of a significant difference between means was performed with Student's t-test. P-values of $<0.05$ were considered to indicate statistically significant differences.

\section{Results}

Effect of cyanate on cytotoxicity. First, we determined whether cyanate affects cell viability by MTT assay and found that cyanate at concentrations up to $1 \mu \mathrm{M}$ did not affect cell viability significantly (Fig. 1).

Effect of cyanate on insulin secretion. The effect of cyanate on insulin secretion was assessed by ELISA assay. As shown in Fig. 2, cyanate decreased insulin secretion significantly in a dose-dependent manner. Cyanate at $0.01 \mu \mathrm{M}$ attenuated insulin secretion by $6 \pm 11 \%$ and at $1 \mu \mathrm{M}$ by $59 \pm 14 \%(\mathrm{P}<0.01)$ compared to the control. When INS-1 cells were stimulated with glucose (5 and $10 \mathrm{G}$ ), insulin secretion in INS-1 cells was also significantly reduced dose-dependently by cyanate treatment (5 G, P<0.05; $10 \mathrm{G}, \mathrm{P}<0.005)$.

Effect of cyanate on ROS generation. To determine the underlying mechanism of the inhibitory effect of cyanate on insulin secretion, ROS generations by cyanate in INS-1 cells were determined. As shown in Fig. 3, no difference in ROS generation in cyanate-treated cultured pancreatic $\beta$ cells was observed compared to the contol.

Effect of cyanate on apoptosis. To determine whether the inhibitory effect of cyanate on insulin secretion was due to apoptosis, we executed FACS analysis and observed that cyanate did not induce apoptosis in INS-1 cells (Fig. 4).

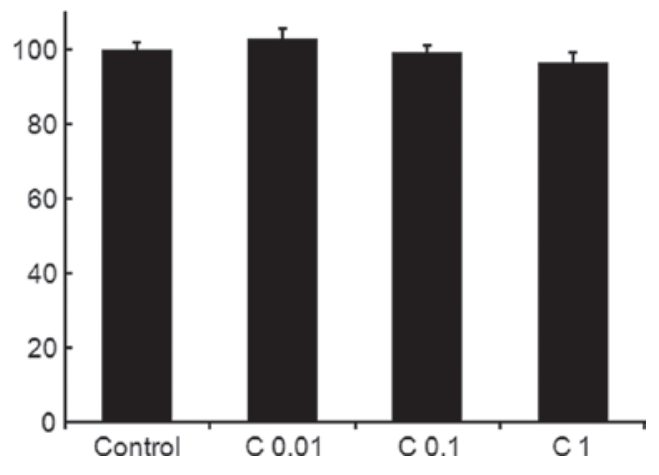

Figure 1. Effect of cyanate on the viability of INS-1 cells. The cells were incubated for 4, 12, 24 and $48 \mathrm{~h}$ in 96-well microplates with various concentrations of cyanate $(0.01,0.1$ and $1 \mu \mathrm{M})$. The cytotoxity of cyanate on the INS- 1 cells was evaluated using the MTT cell proliferation assay kit and expressed as a percentage of viable cells compared to the control. Data are presented as the means \pm SD of 3 different experiments performed in triplicate.

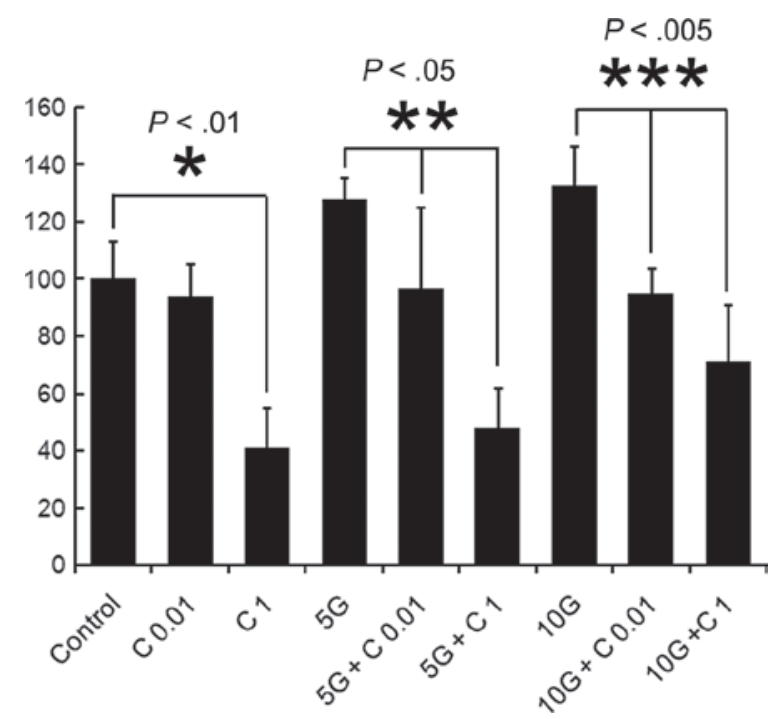

Figure 2. Effect of cyanate on insulin secretion. Secreted insulin was measured using the Insulin ELISA kit. Cells were stimulated with glucose (5 and $10 \mathrm{mM})$ and then treated with cyanate $(0.01$ and $1 \mu \mathrm{M})$. After $24 \mathrm{~h}$, the culture media were collected and analyzed for insulin. The samples were processed according to the manufacturer's instructions. Each column represents the means \pm SD of 3 separate experiments performed in duplicate.

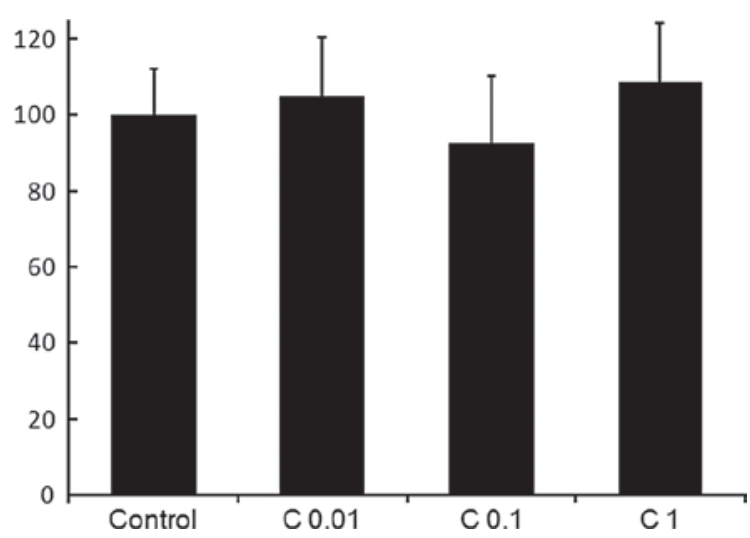

Figure 3. Effect of cyanate on reactive oxygen species (ROS) generation. INS-1 cells treated with $0.01 \mu \mathrm{M}(\mathrm{C} 0.01), 0.1 \mu \mathrm{M}(\mathrm{C} 0.1)$ and $1 \mu \mathrm{M}$ cyanate $(\mathrm{C} 1)$ were incubated for $24 \mathrm{~h}$ and then the amount of generated ROS was measured. Each column represents the means \pm SD of 4 separate experiments performed in duplicate. 

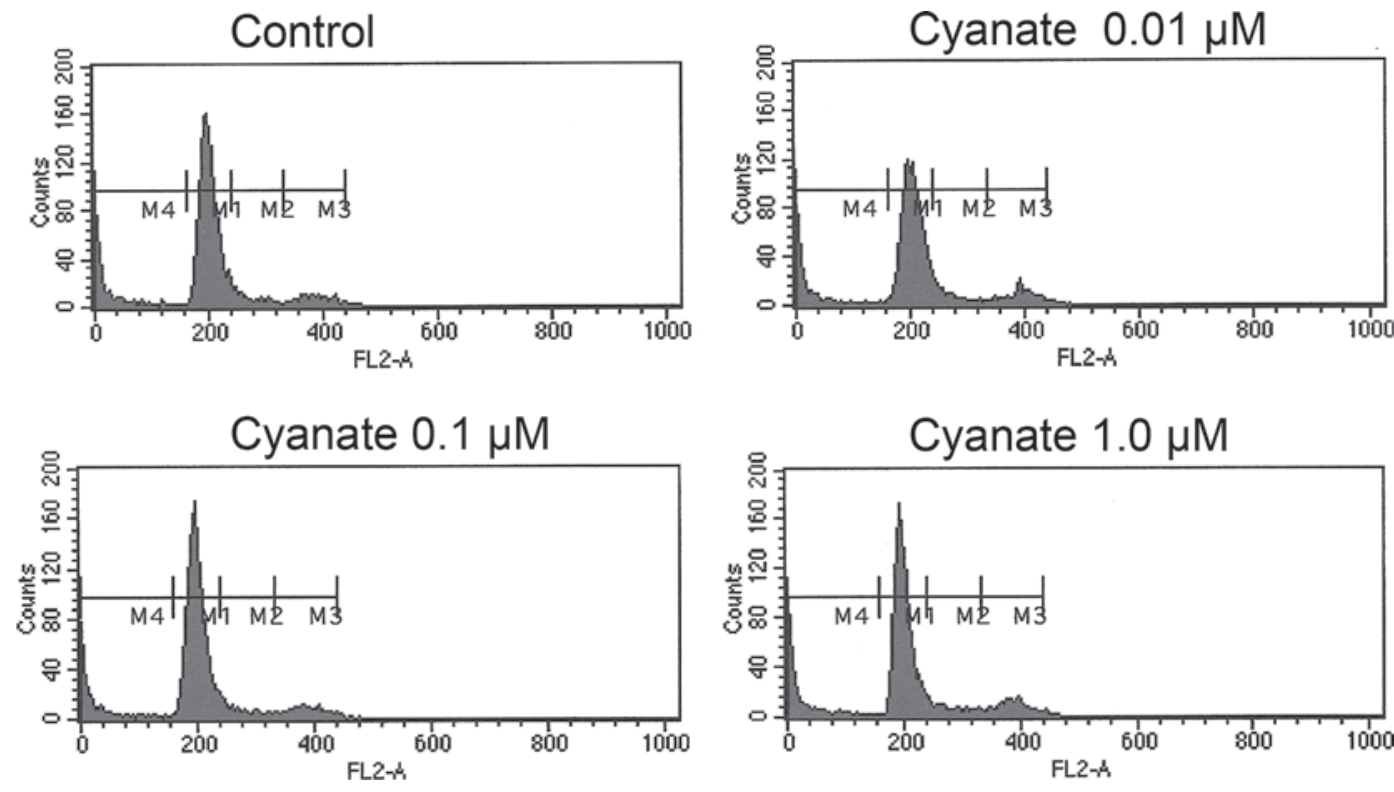

Figure 4. Effect of cyanate on apoptosis. INS-1 cells were treated with $0.01 \mu \mathrm{M}(\mathrm{C} 0.01), 0.1 \mu \mathrm{M}(\mathrm{C} 0.1)$ and $1.0 \mu \mathrm{M}$ cyanate (C 1$)$ and then incubated for $24 \mathrm{~h}$. Apoptosis was measured.

\section{Discussion}

Although evidence has undoubtedly proven that cyanate is produced by the leukocyte heme peroxidase MPO via the $\mathrm{MPO} / \mathrm{H}_{2} \mathrm{O}_{2} / \mathrm{SCN}^{-}$system and MPO-generated cyanate catalyzes protein carbamylation (8), the potential biological role for cyanate in human disease has to date been investigated only in the context of uremia $(2,3)$.

Very few studies concerning the biological function of cyanate have been reported. Cyanate reacts with proteins, including hemoglobin, low density lipoprotein (LDL) and ceruloplasmin $(4,13,14)$. Cyanate-catalyzed carbamylated LDL has been reported to induce proliferation and increase adhesion molecule expression in human coronary artery smooth muscle cells (15). The post-translational binding of cyanate to lysine $\varepsilon-\mathrm{NH}_{2}$ groups in collagen has been demonstrated to impair the oxidative functions of polymorphonuclear neutrophils (16). We recently reported that carbamylated LDL increases ROS and apoptosis via the lectin-like oxidized LDL receptor-mediated pathway in human umbilical vein endothelial cells (17), and carbamylated albumin stimulates microRNA-146 in human renal cell carcinoma (18).

MPO is a heme protein abundantly present in neutrophils, monocytes and certain tissue macrophages, and has emerged as a potential participant in the development of atherosclerosis (19). Increasing evidence supports the involvement of MPO in the pathogenesis of coronary artery disease (20-23). Evidence also suggests that type 2 diabetes mellitus is associated with increased levels of MPO (24).

In the present study, we show that cyanate attenuates insulin secretion in INS-1 pancreatic $\beta$ cells and that this inhibitory effect of cyanate on insulin secretion is not mediated via apoptosis or ROS generation. Since elevated levels of MPO have been observed in both type 1 and type 2 diabetes mellitus $(11,24)$, and cyanate is produced under physiological conditions from MPO, the findings in the present study suggest the possible involvement of cyanate or a cyanate-mediated as yet unidentified carbamylated protein in the development or progression of diabetic complications in cardiovascular disease. Further studies would elucidate the underlying inhibitory mechanisms of cyanate on insulin secretion and identify the involved proteins.

\section{Acknowledgements}

The present study was conducted by the Bisa Research Grant of Keimyung University in 2008 and was supported by the Basic Science Research Program through the National Research Foundation of Korea (NRF) funded by the Ministry of Education, Science and Technology (2011-0013417).

\section{References}

1. Marier JR and Rose D: Determination of cyanate, a study of its accumulation in aqueous solutions of urea. Anal Biochem 7: 304-314, 1964.

2. Fluckiger R, Harmon W, Meier W, et al: Hemoglobin carbamylation in uremia. N Engl J Med 304: 823-827, 1981.

3. Kraus LM, Jones MR and Kraus AP Jr: Essential carbamoylamino acids formed in vivo in patients with end-stage renal disease managed by continuous ambulatory peritoneal dialysis: isolation, identification, and quantitation. J Lab Clin Med 131: 425-431, 1998.

4. Roxborough HE, Millar CA, McEneny J and Young IS: Carbamylation inhibits the ferroxidase activity of caeruloplasmin. Biochem Biophys Res Commun 214: 1073-1078, 1995.

5. Erill S, Calvo R and Carlos R: Plasma protein carbamylation and cecreased acidic drug protein binding in uremia. Clin Pharmacol Ther 27: 612-618, 1980.

6. Hörkkö S, Huttunen, Kervinen K and Kesäniemi YA: Decreased clearance of uraemic and mildly carbamylated low-density lipoprotein. Eur J Clin Invest 24: 105-113, 1994.

7. Kraus LM and Kraus AP Jr: Carbamoylation of amino acids and proteins in uremia. Kidney Int Suppl 78: S102-S107, 2001.

8. Wang Z, Nicholls SJ, Rodriguez ER, et al: Protein carbamylation links inflammation, smoking, uremia and atherogenesis. Nat Med 13: 1176-1184, 2007.

9. Eiserich JP, Baldus S, Brennan ML, et al: Myeloperoxidase, a leukocyte-derived vascular NO oxidase. Science 296: 2391-2394, 2002. 
10. Zhang C, Yang J, Jacobs JD and Jennings LK: Interaction of myeloperoxidase with vascular NAD $(\mathrm{P}) \mathrm{H}$ oxidases derived reactive oxygen species in the vasulature: implications for vascular diseases. Am J Physiol Heart Circ Physiol 285: H2563-H2572, 2003.

11. Heilman K, Zilmer M, Zilmer K, et al: Arterial stiffness, carotid artery intima-media thickness and plasma myeloperoxidase level in children with type 1 diabetes. Dabetes Res Clin Pract 84: 168-173, 2009.

12. Stim J, Shaykh M, Anwar F, et al: Factors determining hemoglobin carbamylation in renal failure. Kidney Int 48: 1605-1610, 1995.

13. Balion CM, Draisey TF and Thibert RJ: Carbamylated hemoglobin and carbamylated plasma protein in hemodialyzed patients. Kidney Int 53: 488-495, 1998.

14. Nilsson L, Lundquist P, Kagedal B and Larsson R: Plasma cyanate concentrations in chronic renal failure. Clin Chem 42: 482-483, 1996.

15. Asci G, Basci A, Shah SV, et al: Carbamylated low-density lipoprotein induces proliferation and increases adhesion molecules expression of human coronary artery smooth muscle cells. Nephrology 13: 480-486, 2008.

16. Jaisson S, Sartelet H, Perreau C, et al: Involvement of lysine 1047 in type I collagen-mediated activation of polymorphonuclear neutrophils. FEBS J 275: 3226-3235, 2008.

17. Son JN, Lho Y, Shin S, et al: Carbamylated low-density lipoprotein increases reactive oxygen species (ROS) and apoptosis via lectin-like oxidized LDL receptor (LOX-1) mediated pathway in human umbilical vein endothelial cells. Int J Cardiol 146 428-430, 2011.
18. Ha E, Bang JH, Son JN, et al: Carbamylated albumin stimulates microRNA-146, which is increased in human renal cell carcinoma. Mol Med Report 3: 275-279, 2010.

19. Nicholls SJ and Hazen SL: Myeloperoxidase and cardiovascular disease. Arterioscler Thromb Vasc Biol 25: 1102-1111, 2005.

20. Hazen SL and Heineche JW: 3-chlorotyrosine, a specific marker of myeloperoxidase-catalyzed oxidation, is markedly elevated in low density lipoprotein isolated from human atherosclerotic intima. J Clin Invest 99: 2075-2081, 1997.

21. Podrez EA, Schmitt K, Hoff HF and Hazen SL: Myeloperoxidasegenerated reactive nitrogen species convert LDL intoan atherogenic form in vitro. J Clin Invest 103: 1547-1560, 1999.

22. Asselberges FW, Reynolds WF, Cohen-Tervaert JW, et al: Myeloperoxidas polymorphism related to cardiovascular events in coronary artery disease. Am J Med 116: 429-430, 2004.

23. McMillen TS, Heinecke JW and LeBoeuf RC: Expression of human myeloperoxidase by macrophages promotes atherosclerosis in mice. Circulation 111: 2798-2804, 2005.

24. Wiersma JJ, Meuwese MC, van Miert JN, et al: Diabetes mellitus type 2 is associated with higher levels of myeloperoxidase. Med Sci Monit 14: CR406-CR410, 2008. 